\title{
Ameliorative Effects of Pseudomonas fluorescence Strains on Growth and Antioxidant Potential of Okra (Abelmoschus esculentus) Plant under Nematode Infection
}

\author{
A. M. Esan, Z. Khan, R. Kiran, T. O. Omolekan, K. A. Aremu, and H. R.Y. Adeyemi
}

\section{ABSTRACT}

\begin{abstract}
Meloidogyne incognita is a plant pathogen causing root-knot nematodes disease in many crops worldwide. Due to the environmental threat on the use of chemical fumigants, there is a need for a biological control method using microbial antagonists on root-knot nematodes disease. Therefore, this study was conducted to screen and evaluate the biocontrol potential of $P$. fluorescens strains against root-knot nematodes. The effectiveness of six $P$. fluorescens strains viz., Pf1, Pf2, Pf3, Pf4, Pf5and Pf6 were tested in vitro and also in pots experiment for their inhibitory activities and biocontrol potential against root-knot nematodes disease caused by Meloidogyne incognita on okra plant. Treatments of the nematode with 1.0-6.0\% concentrations of $10^{8}$ CFU/mL of Pf4 and Pf5 strains caused 70.0-95.0\% inhibition on nematode egg-hatch and $2^{\text {nd }}$ stage juveniles activity. Pf3, Pf4 and Pf5showed a decrease in the number of roots galling with increased root and shoot dry weights of stressed okra plant. Moreover, there was 25.99$36.43 \%, 37.76-79.145 \%$ and $42.62-62.37 \%, 69.83-98.09 \%$ increase in shoot length and leaf areas after $15^{\text {th }}$ and $30^{\text {th }}$ day respectively of $P$. fluorescens inoculation. The inoculated okra plants exhibited higher photosynthetic pigments, higher antioxidant enzymes activity and mineral contents than the nematode treated groups. Higher mineral contents were observed in the roots than the leaves of the okra plant subjected to the nematode infection. The bacteria strains especially Pf4 and Pf3 have considerable potential to reduce the menace of the nematodes in the treated okra plant. Therefore, the strains can be used for crop management against root-knot nematodes disease.
\end{abstract}

Keywords: Antioxidant enzymes, Meloidogyne incognita, Minerals, Okra, Pseudomonas fluorescens.
Published Online: June 05, 2021

ISSN: 2684-5199

DOI: $10.24018 /$ ejbio. 2021.2 .3 .168

\section{A. M. Esan*}

Department of Biochemistry, Faculty of Basic Medical Sciences, University of Ibadan, Nigeria.

(e-mail: adexphotocopa ${ }^{\circledR}$ yahoo.com)

Z. Khan

Division of Plant Quarantine, ICARNational Bureau of Plant Genetic Resources, New Delhi, India.

(e-mail: zkhan64@ gmail.com)

R. Kiran

Division of Plant Quarantine, ICAR-

National Bureau of Plant Genetic Resources, New Delhi, India.

(e-mail: pauraj $@$ gmail.com)

T. O. Omolekan

Biochemistry Department, Bowen University Iwo, Osun State, Nigeria.

(e-mail: toluomon@yahoo.com)

K. A. Aremu

Department of Integrated Sciences, Kwara State College of Education, Nigeria.

(e-mail: aremuka@gmail.com)

H. R. Y. Adeyemi

Department of Biochemistry, Federal University of Technology Minna, Nigeria. (e-mail: titilolaadeyemi@gmail.com)

*Corresponding Author

\section{INTRODUCTION}

Root-Knot-Nematodes are soil-borne plant pathogens responsible for various damage in vegetable crops worldwide, and they are divergent in nature [1]. There are about 97 known species of nematodes but Meloidogyne hapla, Meloidogyne javanica, Meloidogyne incognita and Meloidogyne arenaria are causative organisms for the major crop damage [2]. Meloidogyne spp. induce various changes around the root architecture that affect crop quality and production [3]. Giant cells formed in the root of the plants infested with nematodes provide the nutrients on which nematodes feed. This inhibits the flow of nutrients from the plant roots to aerial parts of the plant [4]. Nematodes cause a deficiency of magnesium which is a major mineral element for chlorophyll synthesis and essential element for phosphotransferases activity in the plant tissue [5], and thus, result to low chlorophyll content and low rates of photosynthesis [6]. It is difficult to control Meloidogyne incognita due to its adaptability in the soil and its wide host range [7], [8]. Okra is prone to various diseases and pests from germination to the harvesting stage. Among these biotic 
factors, the prominent one is nematodes that reduce the quality and quantity of okra products, which is responsible for fifty percent of the overall damage [9]. Over the years, due to environmental restrictions on nematicidal use for controlling plant root-knot nematodes disease, biological control and other eco-friendly disease control measures have recently gained tremendous attention and interest in controlling root-knot nematodes [10]. Certain strains of rhizospheric microorganisms like $P$. fluorescence are able to suppress a variety of plant diseases caused by soil-borne plant pathogens and hence are of considerable agricultural value [11]. P. fluorescence spp promote plants growth through phytohormones production such as cytokinins, gibberellins, indole acetic acid (IAA), and antioxidant enzymes [12]. Previous studies demonstrated that $P$. fluorescence reduces plant infection by generating various metabolites which serve as antagonists to various soil-borne diseases [13]. Therefore, this study seeks to evaluate the potential of $P$. fluorescence spp on the suppression of Meloidogyne incognita $\mathrm{J}_{2}$ activity, egg mass and egg-hatch under in vitro and in vivo studies. We examined the changes in the photosynthetic pigments' levels, antioxidant enzyme activities, growth characteristics, and mineral contents in the nematode-infested okra plants under screen house condition.

\section{MATERIALS AND METHODS}

\section{A. Preparation of Nematode Inoculum}

Nematodes (Meloidogyne incognita) were obtained from the roots of infected okra plants in the experimental screen house at the ICAR-NBPGR, India. The entire roots of infected plants were immersed in a beaker of $0.5 \mathrm{~L}$ of water to remove the soil and other debris. Meloidogyne incognita eggs were removed by handpicking or with the aid of forceps into distilled water $(\mathrm{PH} 7.0)$ in a petri dish through a mesh of $26 \mu \mathrm{m}$. Extraction of the second stage juveniles $\left(\mathrm{J}_{2}\right)$ was done using a modified Baermann funnel method of Southey [14]. The inoculum of the nematode obtained was used for both in vivo and in vitro studies.

\section{B. Preparation of $P$. fluorescens Culture}

Six strains of P. fluorescens were procured from CSIRInstitute of Microbial Technology, Chandigarh, India. (Table I). King's B agar medium was used for culturing of the strains which were incubated at $25{ }^{\circ} \mathrm{C}$ for $48 \mathrm{~h}$. The cultures were picked and sub-cultured in King's B agar medium to obtain pure colonies. A pure colony of each strain was inoculated on the nutrient broth and incubated at $28{ }^{\circ} \mathrm{C}$ for $48 \mathrm{~h}$. Then, the culture was centrifuged at $6200 \mathrm{rpm}$ for $10 \mathrm{~min}$. at $4{ }^{\circ} \mathrm{C}$, and the pellets obtained were washed twice with sterilized distilled water and then re-suspended in sterilized distilled water to an optical density of 0.8 at $600 \mathrm{~nm}$ (approximate cell density of $1 \times 10^{8} \mathrm{CFU} / \mathrm{mL}$ ). Distilled water was used for the dilutions to test the nematicidal effect of P. fluorescens spp. against $M$. incognita in vitro.

\section{Effect of P. Fluorescence spp. on $J_{2}$ Mortality}

The bacteria culture $(0.5 \mathrm{~mL})$ of various concentrations, ranging from $1 \%$ to $6 \%$ of $10^{8} \mathrm{CFU} / \mathrm{mL}$ of each strain of $\mathrm{P}$. fluorescence was placed in cavity blocks containing more than 10 active $\mathbf{J}_{2}$ of Meloidogyne incognita. The active $\mathbf{J}_{2}$ of
Meloidogyne incognita were kept in distilled water as a control and in a nutrient broth that contained no bacterium and also in nutrient broth with bacteria for determining the $\mathrm{LC}_{50}$ (lethal concentration which causes $50 \% \mathrm{~J}_{2}$ mortality) for $24 \mathrm{~h}$ after exposure. After incubation of the active $\mathbf{J}_{2}$ of Meloidogyne incognita in the nutrient broth solution contained bacteria cells. $\mathrm{J}_{2}$ mortality was observed for 5 days using a binocular microscope. $\mathbf{J}_{2}$ were considered dead if they were immobile with a straight structure when touched with a pricking needle. The experiment was in complete randomized design with three replicates.

\section{Pot Experiment}

The seeds of okra (genotype NHe-47-4) were procured from ICAR-NBPGR, India. The seeds were sterilized using $0.1 \%$ sodium hypochlorite for about $2 \mathrm{~min}$, washed in distilled water and five seeds per pot were planted in $10 \mathrm{~kg}$ of sterilized soil in pots with intermittent irrigation to achieve soil water field capacity for the period of the experiment. After two weeks of germination, the seedlings were inoculated with $5 \mathrm{~mL}$ of $M$. incognita $\mathrm{J}_{2}$ suspension in water per pot. For inoculation, roots were exposed and the freshly hatched $M$. incognita $J_{2}$ were introduced with the use of a pipette around the seedling roots and then covered with the soil. Similarly, the bacterial strains (Pf3, Pf4 and Pf5) which showed positive results in in vitro studies were examined under pot experiment in a screen house for the biocontrol potency against $M$. incognita. After two days of nematode inoculation, $1 \mathrm{~mL}\left(10^{8} \mathrm{CFU} / \mathrm{mL}\right)$ of broth solution of the bacteria strains was directly introduced around the roots of okra plant. The treatment sets followed a complete randomized design:

1. Control groups:

a. Normal control (no nematode, no broth, and no bacterium);

b. The broth only (positive control);

c. Nematode only (negative control).

2. P. fluorescence groups:

a. Pf3;

b. Pf4;

c. Pf5.

3. P. fluorescence groups + Nematodes groups:

a. Pf3 + Nematodes;

b. Pf4 + Nematodes;

c. Pf5 + Nematodes.

\section{E. Vegetative Growth Characters and Root Physiology}

After 3 and 6 weeks' inoculation of active $M$. incognita $\mathbf{J}_{2}$ into the soil, growth parameters were estimated from each experimental group. Root physiology was examined through visual means using random plants from each treatment at the end of the experiment.

\section{F. Photosynthetic Pigments Estimation}

The photosynthetic pigments of the okra leaves were determined by using the method of Sukran et al. [15]. A 250 $\mathrm{mg}$ of okra leaves were homogenized with the use of mortar and pestle in $85 \%$ acetone for about $5 \mathrm{~min}$. Centrifugation of the homogenate was done using cold centrifuge at $6000 \mathrm{rpm}$ for $10 \mathrm{~min}$. Estimation of the extract concentration was done using pure $85 \%$ aqueous acetone as a blank in UV/VIS 
spectrophotometer at three wavelengths of 663, 644 and 452 $\mathrm{nm}$ for the carotenoids, chlorophyll a and chlorophyll b.

\section{G. Mineral Concentrations Determination}

\section{Sodium content}

The sodium content of digested powder was estimated by using a flame photometer and expressed in $\mathrm{mg} / \mathrm{g}$ by using the method of Jackson [16].

2. Phosphorus, calcium, and magnesium contents

The phosphorus content of the okra leaf was estimated and expressed in milligram per gram by using the method of Jackson [16].

\section{Potassium content}

Potassium content in the plant samples was estimated by using a flame photometer (models PFP7 and PFP7/C JENWAY) and expressed in milligram per gram according to the method of Jackson [16].

\section{Zinc and iron contents}

The zinc and iron contents of the samples were estimated by using an Atomic Absorption spectrophotometer (PerkinElmer UV-Vis Model) and expressed in milligram per gram according to the method of Jorhem [17].

\section{H. Antioxidant Enzyme Assays}

\section{Enzyme extraction}

A $1 \mathrm{~g}$ of okra leaf was ground in a $10 \mathrm{~mL}$ solution of 0.1 $\mathrm{M}$ potassium phosphate $\left(\mathrm{K}_{2} \mathrm{PO} 4\right)$ buffer and $0.5 \mathrm{mM}$ ethylene diamine tetra acetic acid (EDTA). The leaf homogenate was centrifuged for $20 \mathrm{~min}$ at $15,000 \mathrm{rpm}$ in a $4^{\circ} \mathrm{C}$ centrifuge, and the supernatant was used for enzyme analysis according to the method of Esfandiari et al. [18].

\section{Glutathione peroxidase assay}

Estimation of the glutathione peroxidase activity was done by using the method of Rotruck et al. [19].

3. Superoxide dismutase assay

Estimation of the superoxide dismutase activity was done by using the method of Dhindsa et al. [20].

\section{Catalase assay}

Estimation of the catalase activity was done by using the method of Chen et al. [21].

\section{Statistical Analysis}

Data on percentage growth inhibition and mortality reduction percentage were analysed using ANOVA with the Statistical Package for the Social Sciences (SPSS, 2003), followed by Least Significance Difference and the values are expressed as mean \pm standard deviation using Microsoft Excel package. A significant difference was applied at $\mathrm{p}<$ 0.05 .

\section{RESULTS}

\section{A. Nematicidal Effect of P. Fluorescens on $\mathrm{J}_{2}$ Mortality and on Hatching of the Egg Mass}

In Fig. 1, mortality of the 2nd stage juveniles (J2) of the root-knot nematode was observed after $24 \mathrm{~h}$ at $6 \%$ concentration of Pf3 strain and after $24 \mathrm{~h}$ at $3 \%$ concentration of Pf4 strain when compared with Pf5 strain, broth only and control group

In Fig. 2, Treatments of the root-knot nematode with 1.0$6.0 \%$ concentrations $(108 \mathrm{CFU} / \mathrm{mL})$ of Pf4 and Pf5 strains caused 70.0-95.0\% inhibition of hatching of eggs in the rootknot nematode as compared with Pf3 strain and control groups. On egg mass for egg hatchability, only Pf4 and Pf5 at $1 \%$ and $6 \%$ concentrations respectively completely inhibited egg hatching after 5 days of treatment as compared with control group, where all eggs hatched out after 5 days of treatment.
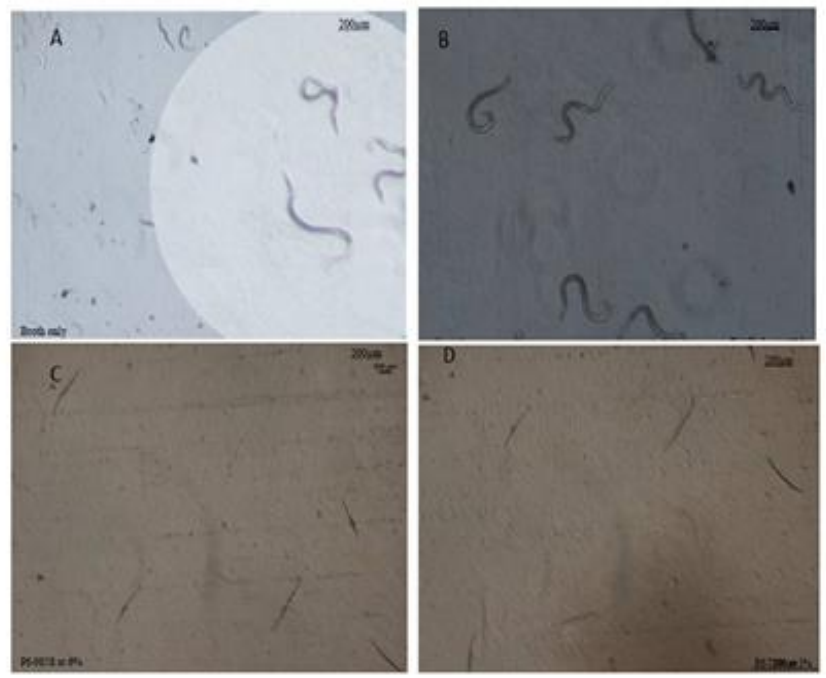

Fig. 1. Culture concentrations of different strains of $P$. fluorescens required for $\mathrm{LC}_{50}$ of $M$. incognita $\mathrm{J} 224 \mathrm{~h}$ after inoculation, (A) effect of broth only (B) effect of distilled water only (C) effect of Pf1 at $6 \%$ concentration (D) effect of Pf3 at $3 \%$ concentration.

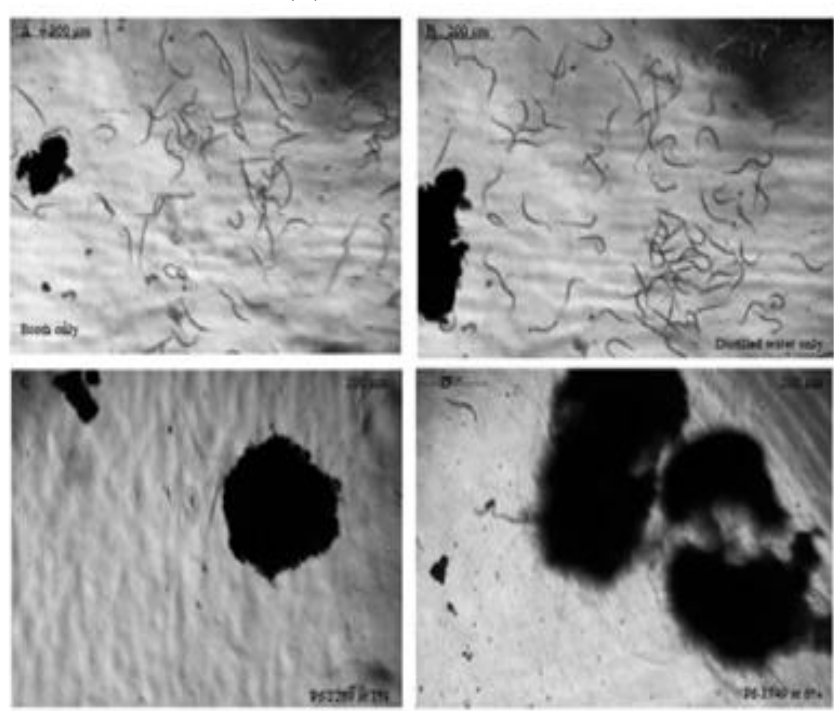

Fig. 2. Images showing the inhibitory effect of $P$. fluorescence on hatching of the egg masses after 5 days of treatment (A) effect of broth only (B) effect of distilled water only (C) effect of Pf4, at $1 \%$ concentration (D) effect of Pf5 at $6 \%$ concentration.

\section{B. Effect of $P$. Fluorescens on Vegetative Growth Characters}

Reduction in the incidence of root gall formation was observed with the inoculation of Pf4 strain in the soil as compared to the untreated control (Fig. 3). A significant $(p<0.05)$ decrease of root and shoot growths of okra plant was observed by the infection of root-knot nematode. However, treatment of infected okra plants with $P$. fluorescens, only Pf5 strain treated plants showed a significant increase in the length of the shoot and leaf area as compared to nematode control group after 15 and 30 days of bacteria inoculation 
(Table I). In the same vein, after 30 days of inoculation, only Pf5 strain treated plants showed $62.37 \%$ and $98.09 \%$ increase in the shoot length and leaf areas of okra plant respectively (Table II). In Table III, a significant effect of $P$. fluorescens on growth parameters of okra plants infected with nematode was observed in Pf3+Nematode and Pf5+Nematode, respectively when compared with the nematode-treated group.
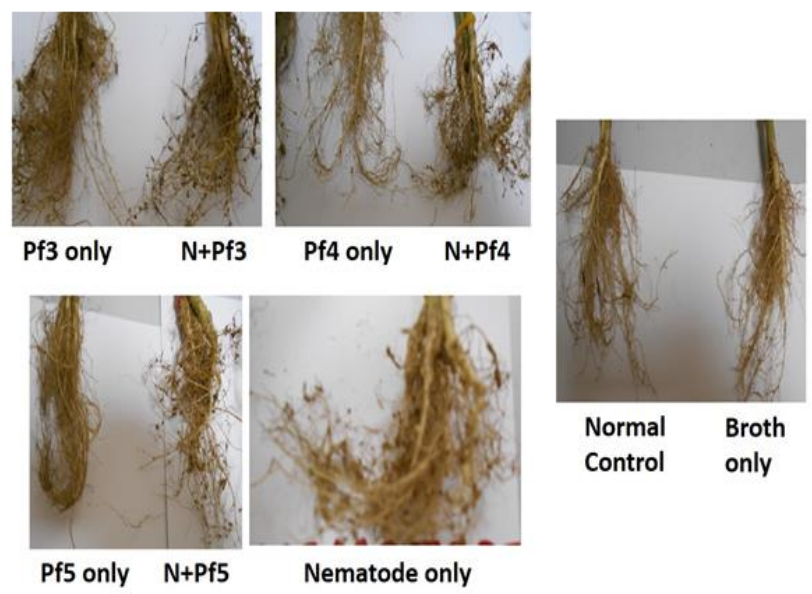

Fig. 3. Effect of P. fluorescens on gall formation in okra roots infected with the nematode.

TABLE I: EFFECT OF P. FLUORESCENS ON OKRA PLANT GROWTH WHEN APPLIED AT 15 DAYS AFTER NEMATODE INOCULATION

\begin{tabular}{ccc}
\hline Treatments & Shoot length $(\mathrm{cm})$ & Leaf area $\left(\mathrm{cm}^{2}\right)$ \\
\hline Pf3 & $14.20 \pm 4.5$ & $40.40 \pm 3.6^{* *}$ \\
Pf3+ Nematodes & $14.80 \pm 2.2$ & $32.45 \pm 8.1$ \\
Pf4 & $15.73 \pm 1.0$ & $30.23 \pm 4.1$ \\
Pf4+ Nematodes & $14.25 \pm 1.5$ & $28.93 \pm 8.3$ \\
Pf5 & $16.75 \pm 1.4^{* *}$ & $32.37 \pm 5.4$ \\
Pf5+ Nematodes & $15.43 \pm 0.9^{*}$ & $37.62 \pm 12.6$ \\
Broth & $16.73 \pm 1.5$ & $33.17 \pm 6.3$ \\
Nematodes & $11.31 \pm 2.1$ & $21.00 \pm 5.3$ \\
Normal Control & $12.75 \pm 0.9$ & $23.00 \pm 3.5$ \\
\hline
\end{tabular}

Values are mean $\pm \mathrm{SD}, \mathrm{n}=3$. **Significant difference at $p<0.05$ when compared with the control group. * Significant difference at $\mathrm{p}<0.05$ when compared with the nematode-treated group.

TABLE II: EFFECT OF P. FLUORESCENS TREATMENT ON OKRA PLANT GROWTH APPLIED AT 30 DAYS AFTER NEMATODE INOCULATION

\begin{tabular}{ccc}
\hline Treatments & $\begin{array}{c}\text { Shoot length } \\
(\mathrm{cm})\end{array}$ & Leaf area $\left(\mathrm{cm}^{2}\right)$ \\
\hline Pf3 & $34.33 \pm 2.7^{* *}$ & $89.04 \pm 19.0^{* *}$ \\
Pf3+ Nematodes & $28.88 \pm 3.5$ & $66.05 \pm 18.5$ \\
Pf4 & $33.33 \pm 1.4$ & $58.16 \pm 16.9$ \\
Pf4+ Nematodes & $31.83 \pm 3.8$ & $63.94 \pm 13.7$ \\
Pf5 & $32.25 \pm 0.8$ & $83.56 \pm 6.8^{* *}$ \\
Pf5+ Nematodes & $32.88 \pm 5.1^{*}$ & $74.58 \pm 17.6^{*}$ \\
Broth & $34.75 \pm 4.8^{* *}$ & $83.79 \pm 24.6^{* *}$ \\
Nematodes & $20.25 \pm 2.2$ & $37.65 \pm 9.5$ \\
Normal Control & $25.88 \pm 4.1$ & $69.03 \pm 25.0$ \\
\hline
\end{tabular}

Values are mean $\pm \mathrm{SD}, \mathrm{n}=3$. **Significant difference at $p<0.05$ when compared with the normal control group. * Significant difference at $p<0.05$ when compared with the nematode-treated group.

\section{Effects of P. Fluorescens and M. Incognita on} Photosynthetic Pigments of the Okra Plant

In Fig. 4, a decrease content of the photosynthetic pigments of okra plants was observed in the nematode-treated group. However, in Fig. 5, treatment with P. fluorescens showed a significant increase in the content of photosynthetic pigments of okra plants as compared to the control group. The nematode had a negative effect on the photosynthetic pigment content of okra plant, but treatment with $P$. fluorescens reduced this negative effect through an increase in the levels of chlorophyll contents in the okra plants with a significant increase observed in $P f 3$ when compared to the nematodetreated group (Fig. 5).

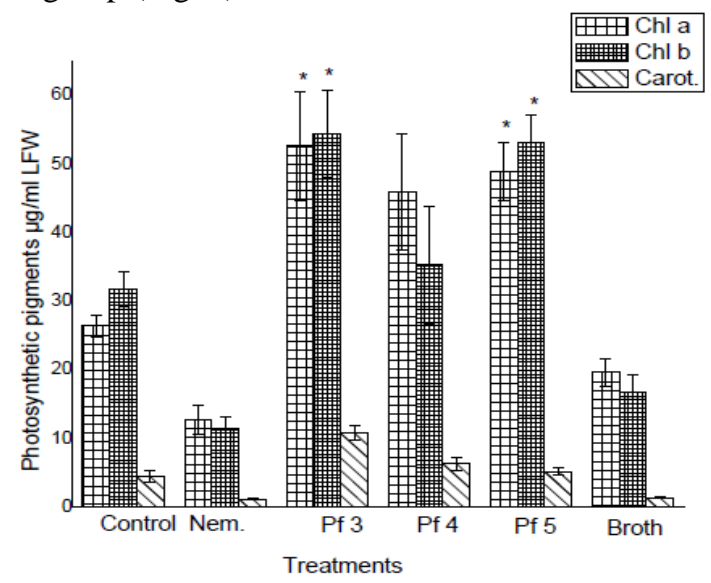

Fig. 4. Effect of $P$. fluorescens on the levels of the photosynthetic pigments in the okra plants. Values are mean $\pm \mathrm{SD}, \mathrm{n}=3$. *Significant difference at $\mathrm{p}$ $<0.05$ when compared with the control group. Where Nem. $=$ Nematodes, $P f=P$. fluorescens

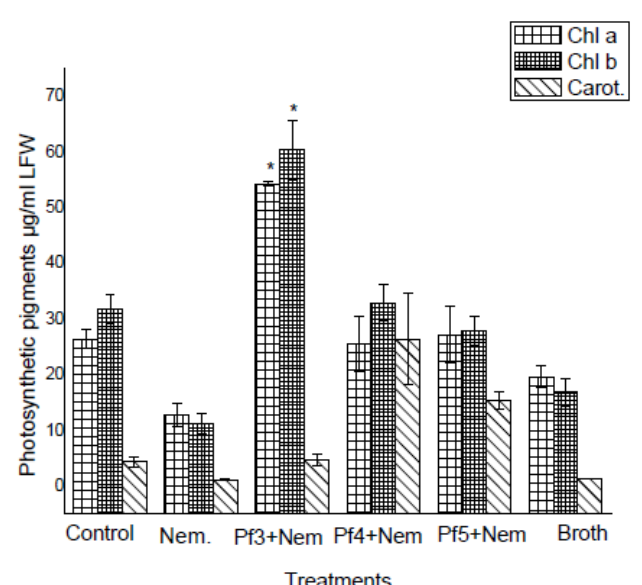

Fig. 5. Combined effects of $P$. fluorescens and nematodes on the levels of the photosynthetic pigments in the okra plants. Values are mean $\pm \mathrm{SD}, \mathrm{n}=$ 3. *Significant difference at $\mathrm{P}<0.05$ when compared with the nematodes, treated group. Where Nem. $=$ Nematodes, $P f=P$. fluorescens.

\begin{tabular}{ccccc}
\multicolumn{5}{c}{ TABLE III: EFFECT OF P. FLUORESCENS ON GROWTH PARAMETERS OF OKRA PLANTS INFECTED WITH THE NEMATODE } \\
\hline Treatments & Root length $(\mathrm{cm})$ & Number of gall & Shoot weight $(\mathrm{g})$ & Root weight $(\mathrm{g})$ \\
\hline Pf3 & $14.63 \pm 1.8$ & - & $19.75 \pm 0.8$ & $0.49 \pm 0.1$ \\
Pf3+ Nematodes & $13.38 \pm 1.8^{*}$ & $60.25 \pm 10.6$ & $14.63 \pm 3.3$ & $0.53 \pm 0.2$ \\
Pf4 & $15.88 \pm 2.4^{* *}$ & - & $15.63 \pm 3.1$ & $0.33 \pm 0.1$ \\
Pf4+ Nematodes & $12.43 \pm 2.8$ & $41.00 \pm 7.2^{*}$ & $14.63 \pm 3.3$ & $0.57 \pm 0.1$ \\
Pf5 & $14.05 \pm 2.2$ & - & $18.00 \pm 5.1$ & $0.37 \pm 0.1$ \\
Pf5+ Nematodes & $11.13 \pm 1.3$ & $48.00 \pm 17.2$ & $17.00 \pm 2.2^{*}$ & $0.57 \pm 0.2$ \\
Broth & $12.25 \pm 2.1$ & - & $15.50 \pm 5.4$ & $0.35 \pm 0.2$ \\
Nematodes & $9.05 \pm 2.2$ & $128.00 \pm 26.7$ & $11.50 \pm 3.8$ & $0.71 \pm 0.4$ \\
NoNormal Control & $1212.75 \pm 2.3$ & - & $1414.50 \pm 3.3$ & $0.30 .33 \pm 0.1$ \\
\hline
\end{tabular}

Values are mean $\pm \mathrm{SD}, \mathrm{n}=3$. **Significant difference at $p<0.05$ when compared with the normal control group. $*$ Significant difference at $p<0.05$ when compared with the nematode-treated group. 


\section{Effects of P. Fluorescens and Nematode on Mineral Contents of the Okra Plant}

In Table IV, and V, the levels of magnesium, calcium, potassium, sodium, zinc, phosphorous, and iron are shown to have increased generally in the and roots of the okra plant treated with $P f 3$ strain as compared to other strains and the control groups. Root-knot nematodes caused a significant reduction in the root minerals content levels. However, inoculation of $P$. fluorescens strains increased minerals content in the roots of the infected okra. Treatment with Pf3 strain showed a significant increase in mineral levels in the okra plant as compared to the nematode-treated groups. Inoculation of $P f 3$ and $P f 4$ strains showed significant increase of minerals content in the leaves of okra plants as compared to Pf5 strain and other groups. Combined effects of $P$. fluorescens and root-knot nematodes on the mineral contents were observed to be higher in the leaves of okra plants inoculated with Pf3 and Pf4 strains. Relatively, higher mineral concentrations were observed in the roots than the leaves of nematode infected okra plants (Table IV and V).

\section{E. Effect of P. Fluorescens on Antioxidant Enzymes Activity of Okra Plants Treated with the Nematode.}

Antioxidant enzymes activity increased in the tissue of okra plant with $P$. fluorescence and nematodes (Fig. 5). A reduction in catalase activity was observed in the okra plant treated with the nematodes.

TABLE IV: EFFECT OF P. FLUORESCENS ON MiNERAL CONTENTS IN THE LEAVES OF OKRA PLANTS INFECTED WITH THE NEMATODE

\begin{tabular}{|c|c|c|c|c|c|c|c|}
\hline Treatments & $\mathrm{Ca}(\mathrm{mg} / \mathrm{g})$ & $\mathrm{Mg}(\mathrm{mg} / \mathrm{g})$ & $\mathrm{K}(\mathrm{mg} / \mathrm{g})$ & $\mathrm{Na}(\mathrm{mg} / \mathrm{g})$ & $\mathrm{Zn}(\mathrm{mg} / \mathrm{g})$ & $\mathrm{P}(\mathrm{mg} / \mathrm{g})$ & $\mathrm{Fe}(\mathrm{mg} / \mathrm{g})$ \\
\hline$P f 3$ & $2.47 \pm 0.42 * *$ & $2.15 \pm 0.34 * *$ & $3.21 \pm 0.33 * *$ & $2.74 \pm 0.32 * *$ & $2.77 \pm 0.24 * *$ & $2.57 \pm 0.42 * *$ & $2.18 \pm 0.34 * *$ \\
\hline Pf3+Nematodes & $1.43 \pm 0.71$ & $0.33 \pm 0.03$ & $1.79 \pm 0.55^{*}$ & $2.12 \pm 0.46^{*}$ & $1.98 \pm 0.06 *$ & $1.72 \pm 0.37 *$ & $0.14 \pm 0.09$ \\
\hline Pf4 & $1.76 \pm 0.31$ & $3.20 \pm 0.11 * *$ & $1.64 \pm 0.29$ & $1.36 \pm 0.44$ & $3.19 \pm 0.16^{* *}$ & $2.08 \pm 0.45$ & $1.87 \pm 0.40$ \\
\hline Pf4+Nematodes & $0.37 \pm 0.02$ & $1.35 \pm 0.06$ & $1.32 \pm 0.06$ & $0.34 \pm 0.03$ & $1.61 \pm 0.14 *$ & $1.53 \pm 0.27 *$ & $1.09 \pm 0.29$ \\
\hline Pf5 & $0.84 \pm 0.06$ & $2.25 \pm 0.54 * *$ & $1.08 \pm 0.40$ & $0.66 \pm 0.06$ & $2.32 \pm 0.94 * *$ & $0.96 \pm 0.16$ & $1.16 \pm 0.10$ \\
\hline Pf5+Nematodes & $0.23 \pm 0.14$ & $0.88 \pm 0.69$ & $0.52 \pm 0.04$ & $0.53 \pm 0.07$ & $0.35 \pm 0.12$ & $0.77 \pm 0.14$ & $1.14 \pm 0.06$ \\
\hline Nematodes & $0.08 \pm 0.02$ & $0.10 \pm 0.01$ & $0.14 \pm 0.09$ & $0.18 \pm 0.02$ & $0.18 \pm 0.05$ & $1.62 \pm 0.06$ & $0.57 \pm 0.07$ \\
\hline Normal Control & $0.85 \pm 0.23$ & $1.05 \pm 0.06$ & $1.93 \pm 0.03$ & $0.63 \pm 0.04$ & $0.94 \pm 0.05$ & $2.07 \pm 0.16$ & $1.15 \pm 0.17$ \\
\hline Broth & $0.15 \pm 0.03$ & $0.43 \pm 0.10$ & $1.39 \pm 0.24$ & $0.45 \pm 0.06$ & $1.05 \pm 0.06$ & $0.75 \pm 0.03$ & $0.57 \pm 0.05$ \\
\hline
\end{tabular}

Values are mean $\pm \mathrm{SD}, \mathrm{n}=3$. **Significant difference at $p<0.05$ when compared with the normal control group. $*$ Significant difference at $p<0.05$ when compared with the nematode-treated group.

TABLE V: EFFECT OF P. FLUORESCENS ON MinERAL CONTENTS IN THE ROOTS OF OKRA PLANTS INFECTED WITH THE NEMATODE

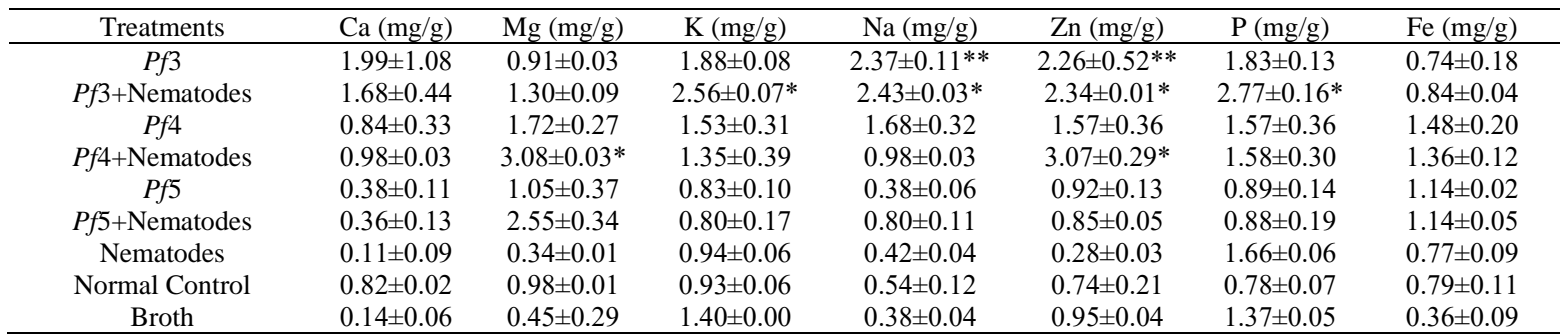

Values are mean $\pm \mathrm{SD}, \mathrm{n}=3$. **Significant difference at $p<0.05$ when compared with the normal control group. * Significant difference at $p<0.05$ when compared with the nematode-treated group.
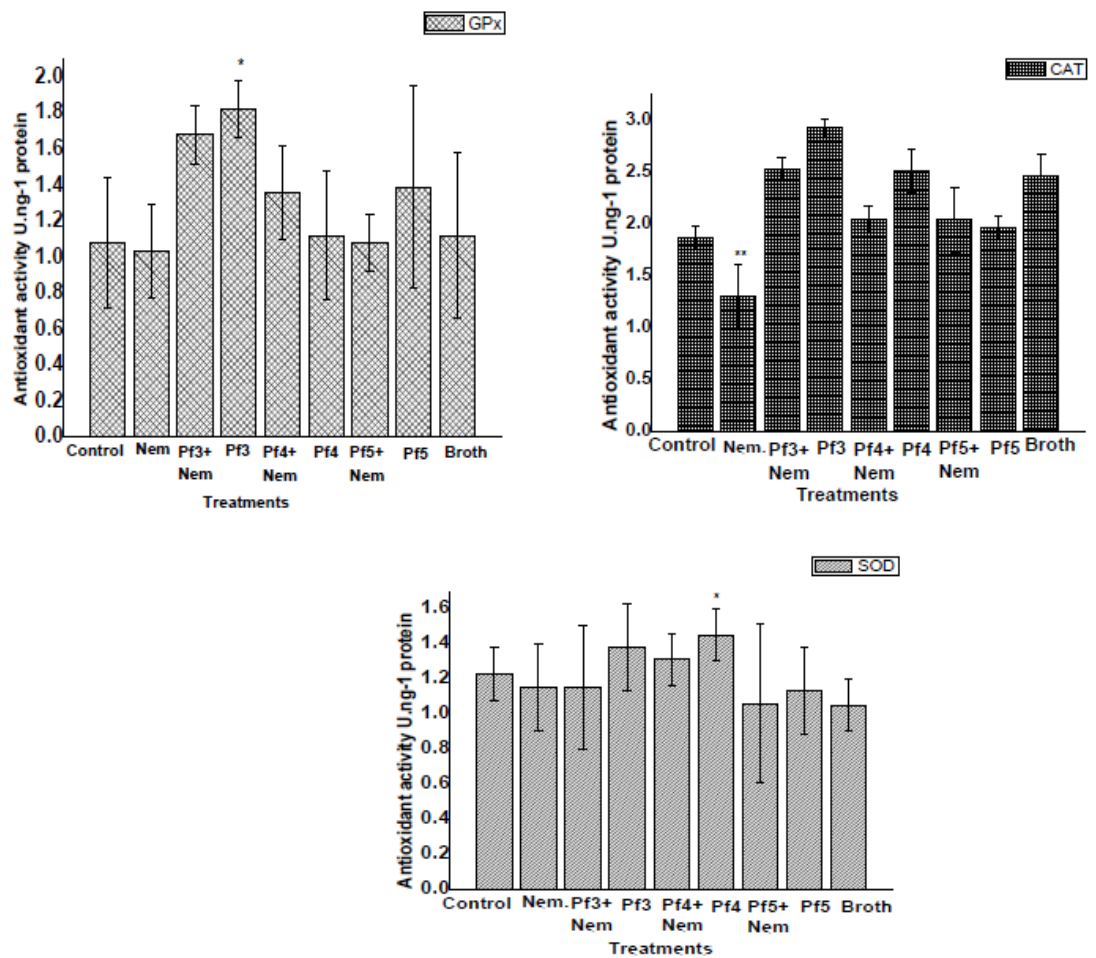

Fig. 6. Effect of Pseudomonas fluorescens on antioxidant enzymes activity of okra plants infected with the nematode. $*$ Significant difference at $\mathrm{p}<0.05$, when compared with the nematodes control group. **Significant difference at $\mathrm{p}<0.05$ when compared with the $P$. fluorescens treated group. Where Pf $=P$. 


\section{DISCUSSION}

This present work focused on the potential of $P$. fluorescence on nematode diseases in okra (Abelmoschus esculentus) plant. $P$. fluorescence at varying culture concentrations reduced the population of $M$. incognita. Bacteria cultures could have contributed to reduced hatchability of the eggs, root galling and activities of $2^{\text {nd }}$ stage juveniles $\left(\mathbf{J}_{2}\right)$ activity. This observation was in concordance with the study of Elyousr [22]; Anita et al. [23]. It was observed that the okra plant inoculated with $P$. fluorescens showed improved growth and development as compared with okra plant infected with Meloidogyne incognita only. Shankat et al. [24] showed that $P$. fluorescence inhibited the penetration of Meloidogyne javanica into tomato plants. San and Shaukat [25] also reported the biocontrol potential of the rhizobacteria against root-knot nematodes.

Increases in the shoot length and leaf area of okra plants as compared to control when $P$. fluorescence was added to the soil after 15 and 30 days following inoculation may be due to phosphate solubilization, indoleacetic acid, and protease enzyme produced by Pseudomonas spp. [26]. The previous report revealed that indole acetic acid synthesis was correlated to the growth of plant stimulation by microorganisms [27]. Siddiqui and Shaukat [28]; Davies et al. [29] observed the induced systemic resistance of $P$. fluorescens in tomato roots against M. javanica. The reduction in the content of the photosynthetic pigments of okra plant under the influence of nematodes could be a result of oxidative stress induced by the nematode infection on the plant, that causes loss of photosynthetic pigments. This observation was in tandem to the report of Karpinski et al. [30] that showed damage to the plant leaf and the chloroplast by the environmental (biotic and abiotic) factors. The significant reduction of the mineral concentrations in the leaves of nematode-inoculated plants could be attributed to the reduction observed in the photosynthetic pigments, which in turn leads to the reduction of plant photosynthetic efficiency. Xu et al. [31] reported a similar result on the reduction in the contents of the nitrogen and phosphorus in cucumber leaves under higher inoculation of nematodes. The higher concentrations of minerals in the roots than in the leaves of the okra plants could be a result of disruption of the root vascular system by the nematodes, which in turn reduces the transport and uptake of the nutrients through the roots to the shoots. Therefore, the application of $P$. fluorescens may possibly increase the reactive oxygen species scavenging enzymes, and thus enhance chlorophyll and mineral contents of the okra plants under the influence of nematodes. Hence, high antioxidant enzyme activities could be interpreted as a higher tolerance of okra plant to oxidative stress caused by the nematode. The alteration in the antioxidant enzyme activities is correlated to the tolerance of the plant to the oxidative stress. Lee et al. [32] reported similar observations. The study of Mittler [33] revealed variations in the levels of antioxidant enzymes which is a signal for the ability to scavenge free reactive oxygen species.

\section{CONCLUSION}

Meloidogyne incognita is an economically important nematode that reduces food security on most cultivated plants, particularly vegetable crops worldwide. P. fluorescens is able to mitigate the negative effect of nematode disease on okra plant caused by Meloidogyne incognita through reduction of gall numbers on the roots when applied as a soil drench. The result also revealed an increase in plant growth parameters, chlorophyll content, the activity of antioxidant enzymes, and reduced gall index in the nematode infected plants. Our study suggests that Pf4 and Pf3 bacterial strains of $P$. fluorescens have considerable potential to reduce the menace of the nematodes in the soil. Furthermore, the strains of $P$. fluorescens can be used for crop management against root-knot nematodes stressed okra plants in the field conditions.

\section{ACKNOWLEDGEMENTS}

We are grateful to the director of RTF_DCS of Centre for Science \& Technology of Non-Aligned and Other Developing Countries (NAM S\&T Centre) and ICARNational Bureau of Plant and Genetic Resources, Pusa Campus, New Delhi, India for their constant support throughout this research work.

\section{CONFLICT OF INTEREST}

Authors have no conflict of interests whatsoever.

\section{FUNDING}

The authors appreciate financial support by RTF-DCS FELLOWSHIP INDIA grant \# NAM - 05/74/2016.

\section{REFERENCES}

[1] D. M. Weller, J. M. Raajmakers, B. B. Gardener, L. S. Thomashow, Microbial populations responsible for specific soil suppressiveness to plant pathogens. Annu. Rev. Plant Pathol. 40, 309-348, 2002.

[2] D. J. Hunt, Z. A. Handoo, Taxonomy, identification and principal species. In: Root-knot nematodes (Eds. Perry R. N., Moens M. and J. L. Starr). CAB International, Wallingford, UK., pp. 55-97, 2009.

[3] M. Moens, R. N. Perry, J. L. Starr, Meloidogyne species a diverse group of novel important plant parasites. p.1-17. In: "Root-Knot Nematodes" (R.N. Perry, M. Moens, J.L. Starr, eds.). CABI Publishing, Wallingford, Oxon, UK, pp. 488, 2009.

[4] H. Melakeberhan, J. M. Webster, Brooke RC, D'Auria JM and Cackette M, Effects of Meloidogyne incognita on plant nutrient concentration and its influence on the physiology of beans. Journal of Nematology, 19, 324-330, 1987.

[5] A. D. M. Glass, Biological roles of the inorganic elements. In: Plant nutrition, an introduction to current concepts. Boston, MA: Jones and Bartlett Publishers. pp. 163-202, 1989.

[6] K. D. Devrajan, G. Rajendran, N. Seenivasan, Nutrient status and photosynthetic efficiency of banana (Musa spp.) influenced by Meloidogyne incognita infected with Pratylenchus penetrans Nematologia Mediterranea, 3, 197-200, 2003

[7] K. R. Kranthi, D. R. Jadhav, S. Kranthi, Wanjari RR, Ali SS and Russell DA, Insecticide resistance in five major insect pests of cotton in India. Crop Protec. 3, 449-460, 2002.

[8] M. Ahmad, M. I. Arif, Z. Ahmad, Resistance to carbamate insecticides in Helicoverpa armigera (Lepidoptera: Noctuidae) in Pakistan. J. Crop protect.10, 427-432, 2001.

[9] M. W. Abbasi, N. Ahmed, M. J. Zaki, S. S. Shaukat, Effect of Barleria acanthoides Vahl. on root-knot nematode infection and growth of 
infested okra and brinjal plants. Pakistan Journal of Bot. 40, 2193 2198, 2008.

[10] M. M. M. Abd-Elgawad, The current status of phytonematode management in Egypt with special reference to applicable nematicides. Egyptian J. Agronemato 6, 33-46, 2008.

[11] Y. Huang, C. Xu, L. Ma, K. Zhang, C. Duan, M. Mo, Characterization of volatiles produced from Bacillus megaterium YFM 3.25 and their nematicidal activity against Meloidogyne incognita. European J. Plant Pathol. 26, 417-422, 2009.

[12] C. L. Patten, B. Glick, Bacterial biosynthesis of indole-3-acetic acid. Can. J. Microbiol., 42, 207-220, 1996.

[13] K. A. Abo-Elyousr, Z. Khan, M. E. Awad, M. F. Abdel-Moneim, Evaluation of plant extracts and Pseudomonas spp. for control of rootknot nematode, Meloidogyne incognita on tomato. Nematropica, 40 289-300, 2010.

[14] J. F. Southey, Laboratory methods for work with plant and soil nematodes. Min. Agric. Fish. Food. HMSO, London, U.K. pp. 202, 1986.

[15] D. Sukran, T. Gunes, R. Sivac, Spectrophotometric determination of chlorophyll-A, B and carotenoid contents of some Algae species using different solvents. Tr. J. of Botany. 22, 13-17, 1998.

[16] M. L. Jackson, Soil chemical analysis. Prentice-Hall of India, New Delhi, pp. 498, 1973.

[17] L. Jorhem, Determination of metals in foodstuffs by atomic absorption spectrophotometry after dry ashing. NMKL Interlaboratory study of lead, cadmium, zinc, copper, iron, chromium and nickel. J. AOAC International, 76, 798-813, 1993.

[18] E. Esfandiari, M. R. Shakiba, S. Mahboob, H. Alyari, M. Toorchi, Water stress, antioxidant enzyme activity, and lipid peroxidation the wheat seedling. J. Food Agric. Environ. 5, 149-153, 2007.

[19] J. T. Rotruck, A. L. Pope, H. E. Ganther, A. B. Swanson, D. G Hafeman, W. G. Hoekstra, Selenium: Biochemical roles as a component of glutathione peroxidase. Science, 179, 588-590, 1984.

[20] R. S. Dhindsa, P. Plumb-Dhindsa, T. A. Thorpe, Leaf senescence correlated with increased levels of membrane permeability and lipid peroxidation, and decreased levels of superoxide dismutase and catalase J. Exp. Botany. 32, 93-101, 1981.

[21] K. Chen, K. Gunte, M. D. Maines, Neurons overexpressing heme oxygenase-1 resist oxidative stress-mediated cell death. J. Neuro chem. 75, 304-313, 2000.

[22] K. A. A. Elyousr, Z. Khan, E. M. M. Award, M. F. A. Moneim, Evaluation of plant extracts Pseudomonas spp. for control of root-knot nematode, Meloidogyne incognita on tomato, Nematropica., 40(2), 288-299, 2010

[23] B. Anita, G. Rajendran, R. Samiyappan, Induction of systemic resistance in tomato against root-knot nematode, Meloidogyne incognita by Pseudomonas fluorescens. Nematol. Medit. 32 (1), 47-51, 2004.

[24] C. Shaukat, P. P. K. Chahal, Effect of thuricide on the hatching of eggs root-knot nematode, Meloidogyne incognita. Current Nematol., 3(1), 41-46, 2002.

[25] J. San, S. S. Shaukat, Biocontrol activity of Rhizobacteria active against plant parasitic nematodes. J. Biofert. Biopest., pp: 54-59, 2009.

[26] A. E. Richardson, Prospects for using soil microorganisms to improve the acquisition of phosphorus by plants. Austral J. of Plant Physiol. 28, 897-906, 2001.

[27] C. L. Patten, B. R. Glick, Role of Pseudomonas putida indoleacetic acid in the development of the host plant root system. Appl. and Environ. Microbiol. 68, 3795-3801, 2002.

[28] I. A. Siddiqui, S. Shaukat, Systemic resistance in tomato induced by biocontrol bacteria against root-knot nematode, Meloidogyne javanica is independent of salicylic acid production. Journal of Phytopathol. $152,48-54,2004$

[29] P. J. Davies, The Plant Hormones: Their Nature, Occurrence, and Functions in P. J. Davies, Eds. Plant Hormones and Their Role in Plant Growth and Development. pp. 1-11, 1987.

[30] S. Karpinski, H. Gabrys, A. Mateo, B. Karpinska, P. M. Mullineaux, Light perception in plant disease defence signalling. Current Opinion in Plant Biology, 6, 390-396, 2003.

[31] H. Xu, W. B. Ruan, Y. B. Gao, X. Y. Song, Y. K. Wei, Effects of rootknot nematodes on cucumber leaf $\mathrm{N}$ and $\mathrm{P}$ contents, soil $\mathrm{pH}$ and soil enzyme activities. Ying Yong Sheng Tai Xue Bao 21, 2038-2044, 2010.

[32] D. H. Lee, Y. Kim, C. B. Lee, The inductive responses of the antioxidant enzymes by salt stress in the rice (Oryza sativa L.). J. Plant Physiol. 158, 737-745, 2001.

[33] R. Mittler, Oxidative stress, antioxidants and stress tolerance. Trends Plant Sci. 7, 405-410, 2002. 